\title{
Characteristics of Toxic Waste from Nine Casting Industries According to Mexican Standards: Prospective Study of West Mexico
}

\author{
Walter Ramírez-Meda, José de Jesús Bernal-Casillas, Luis Alberto López-Tejeda, \\ Gilberto Íñiguez-Covarrubias
}

Departamento de Ingeniería de Proyectos, Universidad de Guadalajara, CUCEI, Guadalajara, México

Email: walter.ramirez@cucei.udg.mx

How to cite this paper: Ramírez-Meda, W., Bernal-Casillas, J. de J., López-Tejeda, L.A. and Íñiguez-Covarrubias, G. (2017) Characteristics of Toxic Waste from Nine Casting Industries According to Mexican Standards: Prospective Study of West Mexico. Journal of Geoscience and Environment Protection, 5, 43-49.

https://doi.org/10.4236/gep.2017.53004

Received: December 3, 2016

Accepted: February 13, 2017

Published: February 16, 2017

Copyright $\odot 2017$ by authors and Scientific Research Publishing Inc. This work is licensed under the Creative Commons Attribution International License (CC BY 4.0).

http://creativecommons.org/licenses/by/4.0

\begin{abstract}
This research analyzed nine casting industries located in western Mexico and their waste streams, including slags, sand, dust and sludge. All of these are considered dangerous by Mexican Legislation due to their concentrations of heavy metals. Analytical results show that lead is the main problem in these wastes. Field sampling showed that these industries do not have any protocol for waste handling and storage.
\end{abstract}

\section{Keywords}

Dangerous Waste, Metal Casting, Slag, Sand, Mexican Legislation, TCLP

\section{Introduction}

The casting industry contributes to industrial development in Mexico and is significant based on the number of jobs it creates and its importance in the manufacturing production. Because of the transformation processes used in the casting industry, it is considered a highly polluting enterprise. Due to the lack of access to adequate environmental technologies by many industrial companies in Mexico, these industries are considered a major source of air pollution emissions and dangerous solid waste that is disposed in dumps or landfills.

In Mexico, more than 1500 companies of varying sizes use smelters for the manufacture of all kinds of products [1]. The casting industry is an important source of employment in Mexico. In the city of Guadalajara alone, basic metal industries have generated more than 1200 jobs according to the Jalisco State Information System (SEIJAL) [2].

Mexico is also recognized as the eleventh largest world producer for manufacturing $78 \%$ of its products for the automotive industry, $8.3 \%$ for agricultural 
machinery, and 3.8\% for industry in general [3].

The main solid waste products generated by the foundry industry are: dusts produced by antipollution devices, slag casting, residual molding sands, sludge pollution control equipment based on water (if there is such equipment).

The slags are byproducts obtained in the fusion of metals that float on the surface of the liquid metal, and they are mainly composed of fluxing oxides, metal loading ash, and furnace lining [4].

When slags are exposed to processes such as separation, crushing, and screening, they are transformed into a granular material that can be widely used in the preparation of construction materials [5] [6].

One of the most significant environmental impacts from the reuse of steel slags is due to the leaching of soluble matrix components when these materials are in direct contact with the ground, exposed to rain, or are in permanent contact with surface and marine waters [7].

The classification of slags in Mexico depends on the process that was used to generate them, as indicated in the Slags Management Plan settled by the Environment and Natural Resources Secretary (SEMARNAT). Those processes are arc electric furnace, pot furnace, basic oxygen converter, high furnace and submerged furnace [8].

Other wastes from the casting industry that can be reutilized are the sands used for the manufacture of molds. These sands are silicates bonded together with binders, and they are used to form molds used in the manufacture of cast iron.

The most common type of sand used in making molds is called green sand. Green sand is composed of sand, clay, carbonaceous material, and water [9].

The smallest enterprises do not reuse sands for manufacturing their own molds. The black sands are then waste that is not reusable in the same casting metal process. Due to dragged or adhered metals in the sand, this waste could be considered dangerous since it has the potential to leach out a high metal content.

A third type of waste produced by the casting industry is dusts, which are not defined as only one kind of waste, as with slags and sand. These dusts could be composed of waste retained by pollution control equipment such as bag filters that trap small particles produced from coal combustion in furnaces.

Other antipollution equipment that utilizes water to trap highly volatile fine particles can produce waste called sludge, but only in enterprises that have this specific pollution control equipment. The sludge is made simply of fine particles that result from combustion mixed with water.

The main dangerous components of slag, sand, dust and sludge are the metal and metalloids present at toxic concentrations (see Table 1), because they can leach out in the presence of an aqueous acid medium. With new technologies and better manufacturing practices in these industries, it is possible to reduce the content of these metal and metalloids so that any generated leachates will have concentrations less than the Maximum Permissible Limits (MPL) established by the Mexican Norm NOM-052-SEMARNT-2005. This norm covers the 
characteristics, the identification procedure, the classification, and the listings of dangerous wastes [10].

In general, according to NOM-052-SEMARNAT-2005, a waste is dangerous in any physical state if it has corrosive, reactive, explosive, flammable, toxic or biologically infectious characteristics, and if its manipulation represents a risk to the ecologic balance, the environment, and public health in general. This work studies the toxicity characteristic of inorganics in casting waste. The Mexican Norm establishes that waste is toxic if the leachate, using the Toxicity Characteristic Leaching Procedure (TCLP) established in NOM-053-SEMARNAT-1993, contains any toxic constituents listed in Table 1 in a higher concentration than established limits [11].

The overall objective of this paper is to determine the dangerous characteristics for toxic inorganic constituents of solid waste generated by nine factories in the metal casting industry, from the Mexican Legislation point of view. The main solid waste products generated and considered are the following: slags, which are byproducts resulting from the casting of refining metal; molding sands, used to manufacture solid molds when casting molten material; dusts from blasting or metal burrs obtained when smoothing out flaws from surplus castings; and sludge from antipollution equipment generated by combining solids with water. The variability and homogeneity of the residues were studied to evaluate the possibility of hazard should they be used in the manufacture of construction materials such as mortars, paving stones, concrete floors, etc.

\section{Methodology}

The experimental part is divided into two sections. The first part focuses on the sampling of waste in the nine casting industries selected for the study, and the second part determines dangerous characteristics through a physicochemical analysis of the waste. The waste and its variability between industries and contaminants is analyzed, and an interval of general confidence is established for every analyzed contaminant to determine if, statistically, it can be considered dangerous waste.

Table 1. Maximum Permissible Limits for inorganic constituents (metals and metalloids) in TCLP leachate. ${ }^{1}$

\begin{tabular}{ccc}
\hline No. CAS & Contaminant & MPL $^{3}, \mathrm{mg} / \mathrm{L}$ \\
\hline $7440-38-2$ & Arsenic & 5.0 \\
$7440-39-3$ & Barium & 100.0 \\
$7440-43-9$ & Cadmium & 1.0 \\
$7440-47-3$ & Chrome & 5.0 \\
$7439-97-6$ & Mercury & 0.2 \\
$7440-22-4$ & Silver & 5.0 \\
$7439-92-1$ & Lead & 5.0 \\
$7440-38-2$ & Arsenic & 5.0 \\
\hline
\end{tabular}

${ }^{1}$ TCLP: Toxicity Characteristic Leaching Procedure. ${ }^{2}$ No. CAS: Chemical Abstracts Service Number. ${ }^{3}$ MPL: Maximum Permissible Limit (for México). 


\subsection{Selection of Casting Waste and Sampling}

Sampling was performed at nine casting companies located in the Guadalajara Metropolitan Zone (ZMG) in Jalisco, Mexico. Each company used a different casting process, involving iron casting slags, lead and aluminum, dust from pollution control equipment and finishing of pieces, and sand from molds utilized for the casting process. The obtained waste was classified as slags, sand, dustor sludge.

The samples for the analytical determinations were taken at the final steps of the industrial processes or from a storage area. As far as possible, sampling was performed by quartering to take a representative sample from the overall volume of waste and considering variations in the process and other variables.

\subsection{Characterization of Hazard Levels by Toxicity of Inorganic Constituents}

To determine whether the waste that was sampled and analyzed can be considered dangerous, the procedure detailed in Mexican Norm NOM-052-SEMARNAT-2005 was applied. This procedure divides the characterization in the analysis into six properties: corrosiveness, reactiveness, explosiveness, environmental toxicity, flammability, and biological infectiousness. But the main interest of the research is environmental toxicity caused by inorganic constitutes: metals and metalloid, their concentrations can obtain by a leachate.

The leachate using the TCLP was prepared and analyzed according the procedure indicated in NOM-053-SEMARNAT-1993. The concentration of each inorganic constituent was determined using an Inductively Coupled Plasma Atomic Emission Spectroscopy (ICP-AES) Thermal Elemental ${ }^{\circledR}$ Iris DUO Model.

The TCLP requires a particle size less than $9.5 \mathrm{~mm}$. Three types of mills used for the slags were tested to determine the most adequate. These tested mills were a ball mill, a rod mill, and a rod mill drum.

The concentrations of inorganic constituents obtained in the TCLP leachate were compared directly with the values in Table 1 to determine whether any are toxic waste.

\section{Results and Discussion}

During the sampling process, it was visually determined that, although the nine enterprises do not have the same casting processes, they share similar waste manipulation and storage procedures. All of the waste is stored in patios or zones that do not have a specific use inside the enterprise layout, so, generally, the wastes are disposed so that they do not affect the main operations in the casting process. They often mix slags, sand, dust and sludge before their final disposition. This is a problem because there is a risk that dangerous waste is mixed with nondangerous waste. In accordance with Mexican legislation, this increases the volume of dangerous waste to dispose.

Visually, most of the slags share similar properties, but vary in color from black to dark gray. Some are vitreous and others are opaque with irregular shapes and 
with different structural integrities. The method used for cooling determines the classification of the slags, because the method affects the shape and the hydraulic properties. This difference makes it evident that they come from different kinds of furnaces, as some companies melt gray iron, lead, or aluminum.

The storage conditions of the waste from the different casting companies participating in the sampling are not adequate for an industrial waste. In some cases, the storage is close to the source of the waste. Those wastes are exposed to the conditions of the environment.

In Tables 2-5, the values preceded by the "<" symbol indicate the Detection Limit of the Method (DLM), expressed as milligrams per liter.

By comparing the concentration value of every inorganic constituent (As, Ba, $\mathrm{Cd}, \mathrm{Cr}, \mathrm{Hg}, \mathrm{Ag}, \mathrm{Pb}$, and $\mathrm{Se}$ ) versus the MPL established by Mexican Legislation for every element, it was found that only $\mathrm{Pb}$ is a potential problem for the sampled enterprises. $\mathrm{Pb}$ values surpass the MPL of $5.0 \mathrm{mg} / \mathrm{L}$ by a factor of $5 \mathrm{in}$ the TCLP leachate.

Table 2. Inorganic constituents concentration in the TCLP leachatefor waste samples.

\begin{tabular}{ccccccccc}
\hline & \multicolumn{7}{c}{ Concentration in leachate TCLP, mg/L } \\
\cline { 2 - 9 } Samples & As & Ba & Cd & Cr & Hg & Ag & Pb & Se \\
\cline { 2 - 9 } & & 0.6096 & 0.0061 & 0.1123 & $<0.001$ & 0.1234 & 35.7300 & 0.0037 \\
Slag 1 & $<0.0042$ & 0.6037 & & \\
Slag 2 & 0.0131 & 0.5939 & 0.0023 & 0.0057 & $<0.001$ & 0.2740 & 0.0185 & 0.0013 \\
Slag 3 & $<0.0042$ & 2.9480 & 0.0061 & 0.1123 & $<0.001$ & 0.1234 & 0.0201 & $<0.0006$ \\
Slag 4 & $<0.0042$ & 0.3795 & 0.0015 & 0.0227 & $<0.001$ & 0.1653 & 0.0302 & $<0.0006$ \\
Slag 5 & $<0.0042$ & 0.5532 & 0.0011 & 0.0279 & $<0.001$ & 0.1597 & 0.0050 & $<0.0006$ \\
Slag 6 & $<0.0042$ & 0.4608 & 0.0028 & 0.0623 & $<0.001$ & 0.1190 & 0.0063 & $<0.0006$ \\
Slag 7 & $<0.0042$ & 0.5316 & 0.0027 & 0.0824 & $<0.001$ & 0.1960 & 0.0071 & $<0.0006$ \\
Slag 8 & $<0.0042$ & 0.6375 & 0.0005 & 0.0196 & $<0.001$ & 0.0662 & 0.0036 & $<0.0006$ \\
Slag 9 & $<0.0042$ & 0.5150 & 0.0016 & 0.0366 & $<0.001$ & 0.2084 & 0.0070 & 0.0083 \\
\hline
\end{tabular}

Table 3. Inorganic constituents concentration in the TCLP leachatefor solid dust samples.

\begin{tabular}{ccccccccc}
\hline & \multicolumn{7}{c}{ Concentration in leachate TCLP, mg/L } \\
\cline { 2 - 9 } Samples & As & Ba & Cd & Cr & Hg & Ag & Pb & Se \\
\hline Dusts 1 & $<0.0042$ & 0.7879 & 0.0031 & 0.0636 & $<0.001$ & $<0.0027$ & 0.0047 & 0.0012 \\
Dusts 2 & $<0.0042$ & 0.8434 & 0.0007 & 0.0220 & $<0.001$ & $<0.0027$ & 0.0039 & 0.0017 \\
Dusts 3 & $<0.0042$ & 0.9657 & 0.0037 & 0.0726 & $<0.001$ & $<0.0027$ & 0.0099 & 0.0051 \\
Dusts 4 & $<0.0042$ & 0.8803 & 0.0020 & 0.0479 & $<0.001$ & $<0.0027$ & 0.0490 & 0.0007 \\
Dusts 5 & $<0.0042$ & 0.6990 & 0.0005 & 0.0203 & $<0.001$ & $<0.0027$ & 0.1188 & 0.0027 \\
Dusts 6 & $<0.0042$ & 1.6000 & 0.0040 & 0.1096 & $<0.001$ & $<0.0027$ & 0.0097 & $<0.0006$ \\
Dusts 7 & $<0.0042$ & 1.1170 & 0.0191 & 0.0417 & $<0.001$ & $<0.0027$ & 0.0163 & $<0.0006$ \\
Dusts 8 & 0.1785 & 0.7652 & 0.7565 & 0.0271 & $<0.001$ & 0.1123 & 255.8000 & 0.1537 \\
Dusts 9 & $<0.0042$ & 0.8915 & 0.0061 & 0.1068 & $<0.001$ & $<0.0027$ & 0.0127 & $<0.0006$ \\
\hline
\end{tabular}


Table 4. Inorganic constituents concentration in the TCLP leachateforsand samples.

\begin{tabular}{lcccccccc}
\hline & \multicolumn{7}{c}{ Concentration in leachate TCLP, mg/L } \\
\cline { 2 - 9 } Samples & As & Ba & Cd & Cr & Hg & Ag & Pb & Se \\
\hline Sands 1 & 0.1351 & 0.3949 & 2.3280 & $<0.0035$ & $<0.001$ & $<0.0027$ & 51.3500 & 0.1783 \\
Sands 2 & $<0.0042$ & 0.9629 & 0.0026 & 0.0394 & $<0.001$ & $<0.0027$ & 0.0869 & 0.0003 \\
Sands 3 & 0.0058 & 2.1000 & 0.0066 & 0.0540 & $<0.001$ & $<0.0027$ & 4.3010 & 0.0072 \\
Sands 4 & $<0.0042$ & 0.5140 & 0.0003 & 0.0203 & $<0.001$ & $<0.0027$ & 0.0115 & 0.0021 \\
Sands 5 & $<0.0042$ & 1.2520 & 0.0018 & 0.0231 & $<0.001$ & $<0.0027$ & 0.2195 & 0.0021 \\
Sands 6 & $<0.0042$ & 0.8634 & 0.0006 & 0.0085 & $<0.001$ & $<0.0027$ & 0.0034 & $<0.00$ \\
Sands 7 & $<0.0042$ & 0.6998 & 0.0001 & 0.0304 & $<0.001$ & $<0.0027$ & 0.0018 & 0.0021 \\
Sands 8 & $<0.0042$ & 0.8824 & 0.0012 & 0.0164 & $<0.001$ & $<0.0027$ & 0.0333 & 0.0025 \\
\hline
\end{tabular}

Table 5. Inorganic constituents concentration in the TCLP leachate for sludge samples.

\begin{tabular}{ccccccccc}
\hline & \multicolumn{7}{c}{ Concentration in leachate TCLP, mg/L } \\
\cline { 2 - 10 } Samples & As & $\mathrm{Ba}$ & $\mathrm{Cd}$ & $\mathrm{Cr}$ & $\mathrm{Hg}$ & $\mathrm{Ag}$ & $\mathrm{Pb}$ & $\mathrm{Se}$ \\
\hline Sludge 1 & 0.0408 & 1.0210 & 0.5513 & 0.0203 & $<0.001$ & $<0.0027$ & 34.1700 & 0.0141 \\
Sludge 2 & $<0.0042$ & 0.6384 & 0.0307 & 0.0018 & $<0.001$ & $<0.0027$ & 1.8160 & 0.0049 \\
Sludge 3 & $<0.0042$ & 0.5144 & 0.3871 & $<0.0035$ & $<0.001$ & $<0.0027$ & 39.8800 & 0.0154 \\
\hline
\end{tabular}

Cd was found in only one sample at a concentration over the MPL for this metal $(1.0 \mathrm{mg} / \mathrm{L})$.

Although this sampling was only prospective, it is evident that, in most cases, the waste from casting companies can be considered nondangerous according to its inorganic toxicity. This conclusion has a direct impact on disposition and operation costs. To corroborate this hypothesis, it would be necessary to conduct more detailed statistic studies for each company to determine the safe concentration limits of $\mathrm{Pb}$ and conclude whether each specific waste can be considered nondangerous.

\section{Conclusions}

During the sampling stage at the participating companies, it became clear that none of them have a defined plan for the handling and storage of their waste. It is necessary for proper procedures and good operating practices to be determined at this point.

Mixing dangerous waste with non-dangerous waste involves higher costs for the company as it increases the volume of dangerous waste. This is a consequence of the negligent handling of waste.

The selections of casting equipment and raw materials used in the casting may reduce the risk of generating dangerous waste based on inorganic toxicity. It is convenient to perform more detailed statistic studies for every process and type of casting to definitely determine whether each waste is dangerous or non-dangerous. 


\section{References}

[1] Dirección General de Industrias Pesadas y de Alta Tecnología (2012) Monografía del Sector Siderúrgico de México, 2011. Secretaría de Economía, Méxco, DF.

[2] Sistema Estatal de Información Jalisco (2013) Actividad Económica de México y Jalisco. Evaluación mensual. Septiembre de 2013. SEIJAL, Guadalajara, Jalisco, México.

[3] FUNDIGEX (2008) Cámara de Comercio de Bilbao. Jornadas y seminarios. La mejora en la industria de la fundición mexicana atrae el interés de las empresas vascas.

http://camarabilbao.com/ccb/contenidos.item.action?id=8435514\&menuId=596553 18onlypath=true

[4] SEMARNAT-CANACERO (2006) Metodología para establecerel plan de manejo de escorias generadas en los procesos de fabricación de hierro, aceros y ferroaleaciones SEMARNAT, México, DF.

[5] Frías, M., San José, T. and Vegas, I. (2010) Árido siderúrgico en hormigones: Proceso de envejecimiento y su efecto en compuestos potencialmente expansivos. Materiales de construcción, 60, 33-46. https://doi.org/10.3989/mc.2019.45007

[6] Frías Rojas, M., Sánchez de Rojas, M.I. and Uría, A. (2002) Estudio de la inestabilidad en escorias negras de horno de arco eléctrico. Materiales de construcción, 52, 79-83. https://doi.org/10.3989/mc.2002.v52.i267.328

[7] Gomes, J. and Pinto, C. (2006) Leaching of Heavy Metals from Steelmaking Slags. Revista de Metalurgia, 42, 409-416.

[8] Vázquez, E.R. and Barra, M. (2001) Reactividad y expansión de las escorias de acería de horno de arco eléctrico en relación con sus aplicaciones en la construcción. Materiales de Construcción, 51, 137-148. https://doi.org/10.3989/mc.2001.v51.i263-264.359

[9] Suárez Lisca, L.H. (2014) La contaminación en la industria de la fundición. Ecología, Universidad Central "Marta Abreu” de las Villas, Cuba.

[10] SEMARNAT (2006) Norma Oficial Mexicana NOM-052-SEMARNAT-2005. Que establece las características, el procedimiento de identificación, clasificación y los listados de los residuos peligrosos. Diario Oficial de la Federación. p. 32.

[11] SEMARNAT (1993) Norma Oficial Mexicana NOM-053-SEMANART-1993. Que establece el procedimiento para llevar a cabo la prueba de extracción para determinar los constituyentes que hacen a un residuo peligroso por su toxicidad al ambiente. Diario Oficial de la Federación. p. 16. 